\title{
Constitutional Basis for Metropolitan and Provincial and Local Government Systems in Zimbabwe: Creating a New Political Dispensation
}

\author{
Dr. S.B.M. Marume \\ BA, Hons BA, MA (Unisa), MAdmin, MSoc Sc, PhD (CUAS) \\ Senior Lecturer and Acting Chairperson, Department of Public Administration, Zimbabwe Open University
}

\begin{abstract}
Zimbabwe, which obtained its independence from Great Britain in April, 1980, after a hard liberation struggle, has been since then a unitary state with lower tiers of government being run on acts and directions from central government without a constitutional basis. When a Government of National Unity made up of ruling ZANU (PF) and MDC formations was adopted between 2008 and 2012 as a consequence of inconclusive elections of March and June, 2008; it became apparent that powers and responsibilities had to be devevolved to lower tiers of government if meaningful political participation and genuine community development priorities were to take place peacefully and progressively. However, after protracted and sometimes acrimonious debates, political and constitutional consultations resulted in a new Constitution of Zimbabwe Act, 2013 [Amendment No. 20 of 2013] which, for the first time in the history of the country, paved way for establishing a three tier system of government, namely, the central government at the top; metropolitan and provincial councils in the middle; and local authorities at the lowest level; thus creating a new vibrant, representative, and democratic political and constitutional dispensation which is the subject of this article.
\end{abstract}

Keywords: democracy, representation, powers, devolution.

\section{Purpose of the Article}

This is to:

- show the firm constitutional basis for participating in and establishing metropolitan, provincial and local authorities in Zimbabwe;

- outline the representation and structural composition of metropolitan and provincial councils;

- show the political and constitutional directions to all subordinate authorities, and

- indicate functional areas of jurisdiction.

\section{Background}

The Zimbabwe African National Union (Patriotic Front), which won the elections of February 1980 formed the first African majority rule government. It remained in power unchallenged until 2007. Its policies were generally centralist. These did not allow organised effective democratic participation by communities in the running of their own affairs on a devolved basis. Determination of community development priorities at local levels was minimal. Democratic local leadership and true community development have remained elusive. Instead, resentment and political opposition was mounting amongst the enlightened citizenry against centralism. Unity Government of ZANU PF and MDC parties between 2008 and 2012 resulted in intensive and protracted political and constitutional debates that paved the way for a new political system that resulted in the constitutional creation of much more vibrant, democratic and representative metropolitan and provincial and local government systems in Zimbabwe. This has meant creating a new political dispensation that should enable shaping the $21^{\text {st }}$ century independent unitary great Zimbabwe by opening up unlimited leadership development potentials through provincial and enabling local government councils, by whatever name called, to democratically articulate, represent, and manage the affairs of responsible people in urban and rural areas within the communities they reside. This then provides a new contemporary democratic public administration perspective for the country.

\section{Brief history of Zimbabwe}

Zimbabwe, occupied by the British South Africa Company from $1890-1921$ as a colony known as Southern Rhodesia; self - governing $(1921-64)$ and a rebellious settler state called Rhodesia (1965 - 79); a unitary state which attained its independence under an African majority rule from Great Britain on April 18, 1980 under the name the Republic of Zimbabwe after 90 years of white rule $(1890-1980$, of which 15 years $(1964-79)$ were protracted bitter liberation war period; thus having used the substantially amended Lancaster House Constitution (1980 - 2012) approved in a national referendum conducted on March 16, 201,3 a new home grown constitution which provides for a much more vibrant political and constitutional dispensation giving rise to a three - tier governmental structure for the country. The country under the name the Republic of Zimbabwe is now governed by a constitution which provides the supreme law of the land.

\subsection{Types of areal authorities in Zimbabwe}

It is no longer optional but obligatory for Zimbabwe to have metropolitan and provincial councils and local authorities as subordinate institutions as stipulated in the Constitution, 2013

Consistent with section 5 of the Constitution 2013, the tiers of government in Zimbabwe are:-

1) the national or central Government at the top;

2) metropolitan and provincial councils in the middle; and 


\section{International Journal of Science and Research (IJSR) \\ ISSN (Online): 2319-7064 \\ Index Copernicus Value (2013): 6.14 | Impact Factor (2014): 5.611}

3) local authorities at the bottom, that is to say -

a) urban councils, by whatever name called, to represent and manage the affairs of people in urban areas; and

b) rural councils, by whatever name called, to represent and manage the affairs of people in rural areas within the districts into which the provinces are divided.

\subsection{Implications for the Zimbabwean Citizen}

What this now means is that the Zimbabwean citizen is confronted with three types or areal authorities, that is, central Government, metropolitan and provincial councils, and local authorities; all having legislative powers. By 'legislative powers' we mean the authority by which either $\underline{\text { acts }}$ or ordinances or by - laws or regulations may be passed.

The central authority has power in and over the Republic of Zimbabwe. By 'central authority' we mean the Zimbabwean Parliament and its relevant institutions. Constitutionally, the State President is the head of both the legislative and the executive organs in the Republic. A group of ministers collectively known as the cabinet, with the state president at its head, act as councillors of the State President and exercise the highest effective governmental authority in the country.

The legislature consists of the State President, the Senate and the National Assembly. The State President is elected by the voters directly in harmonized elections; the Senate of almost wholly elected through proportional representation; the House of Assembly which is now called the National Assembly is elected every five years by the enfranchised citizens of the country at a general election. A minister must be a member of either the Senate or the National Assembly. However, the State President is allowed in terms of the new constitution to appoint five members outside Parliament as ministers. Members of the National Assembly are elected in Zimbabwe entirely on their party - political affiliations. The party with the greatest number of representatives in the National Assembly gains control over matters of State and is then known as the government of the day.

The constitution authorizes Parliament to pass acts on any matter. Acts may, therefore, be adopted to change the status and powers of the provincial and metropolitan and local authorities.

This article examines in preliminary terms the constitutional basis of the subordinate authorities: metropolitan and provincial and local authorities.

\subsection{Constitutional Requirements}

For the first time in the history of Zimbabwe, metropolitan and provincial and local authorities are provided for in the Constitution of the country.

\subsubsection{Preamble to chapter 14 on metropolitan and provincial and local authorities}

Divisibility of and breakaway from Zimbabwe will be discouraged and treated as illegal
The Constitution 2013 [chapter 14] states in the preamble, that there shall be

a) the preservation of national unity in Zimbabwe and the prevention of all forms of disunity and secessionism;

b) the democratic participation in government by all citizens and communities of Zimbabwe; and

c) the equitable allocation of national resources and the participation of local communities in the determination of development priorities within their areas;

d) there $\underline{\text { must }}$ be devolution of power and responsibilities to lower tiers of government in Zimbabwe.

\subsubsection{Devolution of governmental powers and} responsibilities

The highly contestable concept of devolution of governmental power by various political parties has been settled as stated in this constitution.

According to section 264 on devolution of governmental powers and responsibilities, it is provided that:

1) Whenever appropriate, governmental powers and responsibilities $\underline{\text { must }}$ be devolved to provincial and metropolitan councils and local authorities which are competent to carry out those responsibilities efficiently and effectively.

2) The objectives of the devolution of governmental powers and responsibilities to provincial and metropolitan councils and local authorities are:

a) To give powers to local governance to the people and enhance their participation in the exercise of the powers of the State and in making decisions affecting them;

b) To promote democratic, effective, transparent, accountable and coherent government in Zimbabwe as a whole;

c) To preserve and foster the peace, national unity and indivisibility of Zimbabwe;

d) To recognise the right of communities to manage their own affairs and to further their development;

e) To ensure the equitable sharing of local and national resources; and

f) To transfer responsibilities and resources from the national government in order to establish a sound financial base for each provincial and metropolitan council and local authority.

\subsubsection{General principles of metropolitan, provincial and local government}

Certain basic principles need to be followed by subordinate authorities to guarantee prediction and consistency in the conduct of public administration at those levels.

(1) In terms of section 265, provincial and metropolitan councils and local authorities must, within their sphere:

a) ensure good governance by being effective, transparent, accountable and institutionally coherent;

b) assume only those functions conferred on them by this Constitution or Act of Parliament;

c) exercise their functions in a manner that does not encroach on the geographical, functional or institutional integrity of another tier of government;

d) cooperate with one another, in particular by 


\section{International Journal of Science and Research (IJSR) \\ ISSN (Online): 2319-7064}

Index Copernicus Value (2013): 6.14 | Impact Factor (2014): 5.611

e) informing one another of, and consulting one another on, matters of common interest;

f) harmonising and coordinating their activities;

g) preserve the peace, national unity and indivisibility of Zimbabwe;

h) secure the public welfare; and

i) ensure the fair and equitable representation of people within their areas of jurisdiction.

(2) All members of local authorities must be elected by registered voters within the areas for which the local authorities are established.

(3) An Act of Parliament must provide appropriate mechanism and procedures to facilitate coordination between central government, provincial and metropolitan councils, and local authorities.

\subsubsection{Conduct of employees of provincial and local} government

Metropolitan and provincial and local authorities need fully employed public servants to implement their policy decisions

Consistent with section 266 of the Constitution, 2013,

1) Employees of provincial and metropolitan councils and local authorities must act in accordance with this constitution and the law.

2) No employee of a provincial or metropolitan council or a local authority may, in the exercise of their functions:-

a) Act in a partisan manner;

b) Further the interests of any political party or causes;

c) Prejudice the lawful interests of any political party; or

d) Violate the fundamental rights or freedoms of any person.

3) Employees of provincial and metropolitan councils and local authorities must not be office bearers of any political party.

4) An Act of Parliament must make provision to ensure the political neutrality of employees of provincial and metropolitan councils and local authorities.

Figure 1

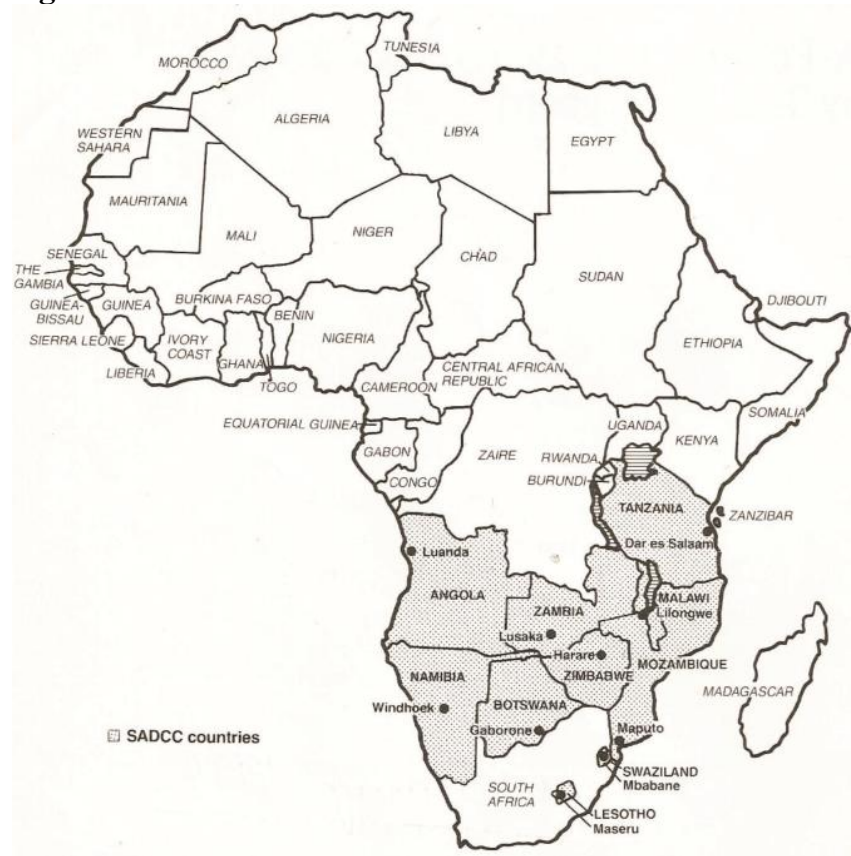

Map of Zimbabwe: Administrative provinces and districts and their boundaries

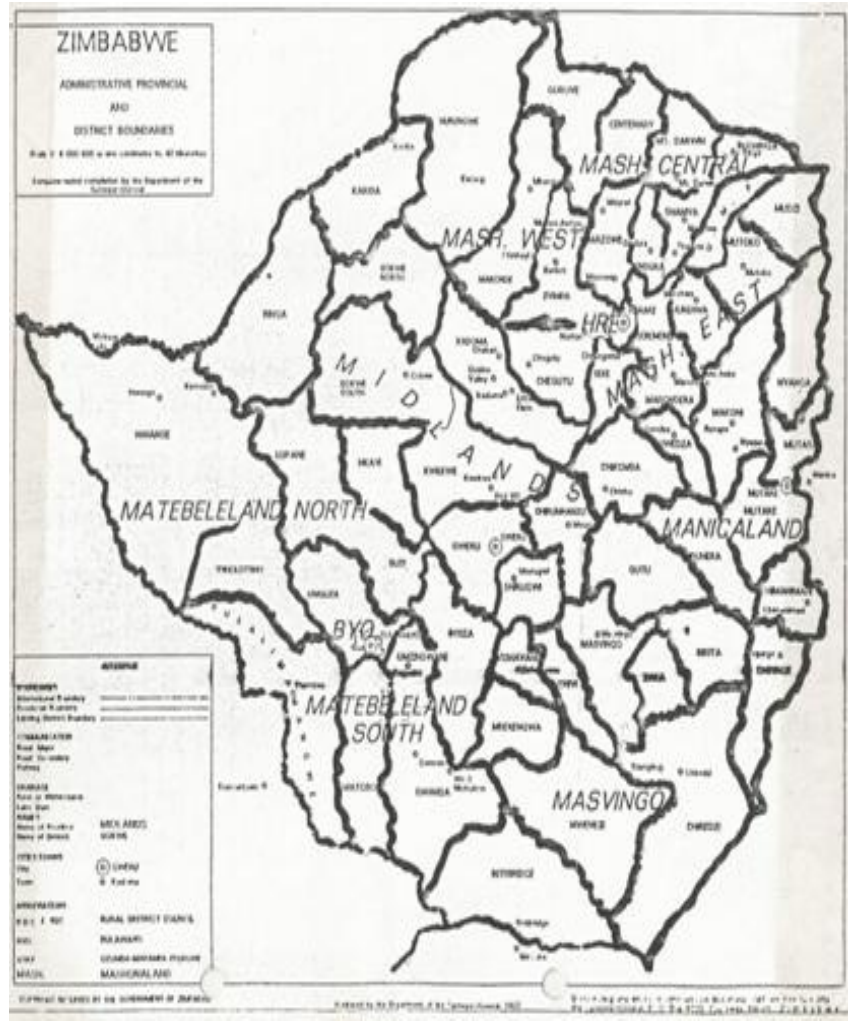

Figure 2

The country has to be divided into identifiable geographical areas for manageability purposes.

\section{Provinces and districts in Zimbabwe}

In terms of section 267 of the Constitution provinces and districts of Zimbabwe:

1) The provinces into which Zimbabwe is divided are:-

a) Bulawayo Metropolitan Province

b) Harare Metropolitan Province

c) Manicaland

d)Mashonaland Central

e) Mashonaland East

f) Mashonaland West

g)Masvingo

h) Matebeleland North

i) Matebeleland South

j) Midlands;

whose boundaries are fixed under an Act of Parliament.

Consultation on the alteration of boundaries is inevitable but consultation with the affected communities, involvement of electoral commission and consent of the State President on necessary ingredients.

2) An Act of Parliament -

a) Must provide for the division of province into districts; and

b) May provide for the alteration of provincial and district boundaries; after consultation with the Zimbabwe Electoral Commission and the people in the provinces and districts concerned.

Figure 1: Africa and SADC Countries 


\section{International Journal of Science and Research (IJSR) \\ ISSN (Online): 2319-7064}

Index Copernicus Value (2013): 6.14 | Impact Factor (2014): 5.611

\section{Metropolitan councils}

As stated in section 267 there are only two metropolitan provinces, namely,

- Bulawayo Metropolitan Province and

- Harare Metropolitan Province.

\section{Representation on metropolitan councils}

Representations to metropolitan councils need to be properly stated and regulated to ensure good governance.

In terms of section 269 on Metropolitan Councils

1) For each of the metropolitan provinces there is a metropolitan council consisting of:

a) In the case of Bulawayo, the mayor of the City of Bulawayo, who shall be the chairperson of the BULAWAYO METROPOLITAN COUNCIL;

b) In the case of Harare

- The mayor of the City of Harare, who shall be the chairperson of the HARARE METROPOLITAN COUNCIL, and

- The mayor or chairperson of the second largest urban local authority within the province, who shall be the deputy chairperson of the Harare Metropolitan Council;

c) all the members of the National Assembly whose constituencies fall within the metropolitan province concerned;

d) the women members of the National Assembly who are elected in terms of section 124 (1) from the metropolitan province concerned;

e) the Senators elected from the metropolitan province concerned; and

f) the mayors and deputy mayors and the chairpersons and deputy chairpersons, by whatever title they are called, of all local authorities in the metropolitan province concerned.

\section{Vacant seats in Metropolitan Council}

2) The seat of a member of a council referred to in -

a) Paragraph (a) or (b) of subsection (1) becomes vacant if the member ceases to be mayor, deputy mayor or chairperson, as the case may be;

b) Paragraph (c), (d) or (e) of subsection (1) becomes vacant if the member vacates his or her seat in Parliament;

c) Paragraph (f) of subsection (1) becomes vacant if the member ceases to be a mayor, deputy mayor, chairperson or deputy chairperson, as the case may be, of a local authority in the metropolitan province concerned.

Figure 3

Representations on Bulawayo Metropolitan Council

\begin{tabular}{|ll|}
\hline 1 & Chairperson - Mayor of Bulawayo \\
1 & Deputy Mayor of City of Bulawayo \\
12 & Members of National Assembly \\
6 & Women members of National Assembly \\
6 & Senators \\
\hline
\end{tabular}

Figure 4

Representations on Harare Metropolitan Council 48-MEMBER COUNCIL

1 Chairperson [Mayor of City of Harare]

1 Deputy Chairperson [Mayor of Chitungwiza Urban

Council]

29 Members of National Assembly

6 Women Members of National Assembly

6 Senators

1 Deputy Chairperson - Chitungwiza Town Council

2 Chairperson and Deputy Chairperson - Ruwa

Town Council

2 Chairperson and Deputy Chairperson - Epworth Local Board

\section{$\underline{\text { Figure } 5}$}

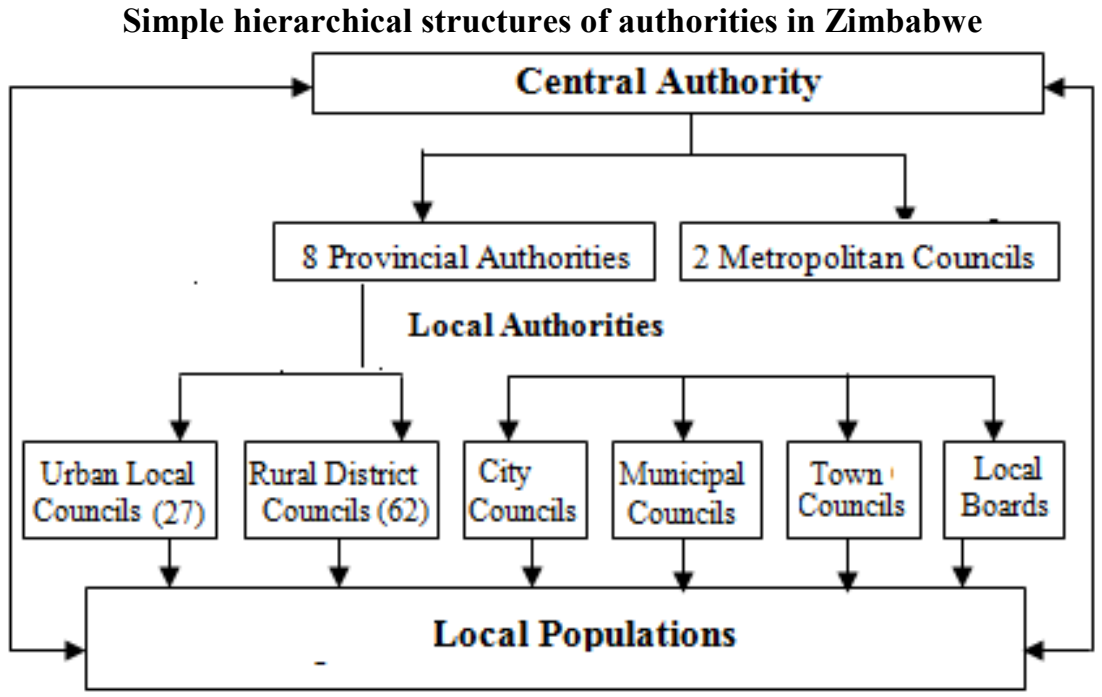




\section{Figure 6}

Showing reasonable hierarchical relations between Harare Metropolitan Council and Local Authorities in Harare Metropolitan Province

Harare Metropolitan Authority

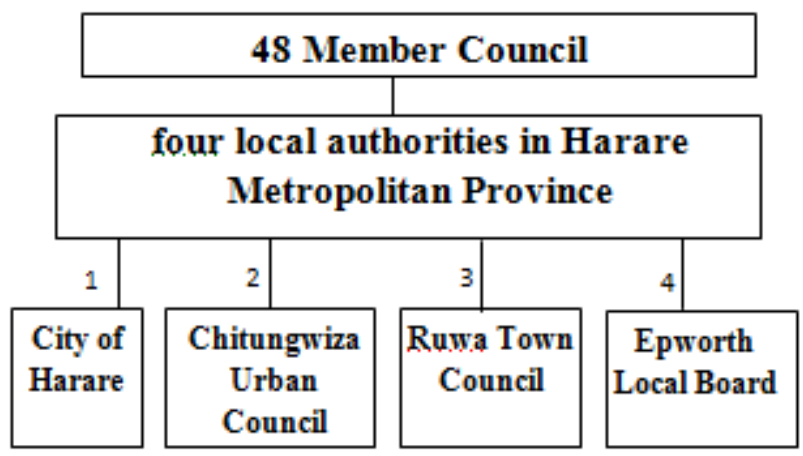

\section{Committees of Metropolitan Councils}

The committee system appears to be a universal phenomenon for the better management of governmental affairs, and there needs to be a legal basis for this.

For the better exercise of their functions, metropolitan councils may establish committees but each such committee must be presided over by a member referred to in section 269 (1) (b). In simple terms, the chairperson of each such committee shall be the chairperson or deputy chairperson of the metropolitan council.

\section{General provisions relating to Metropolitan Councils}

In terms of section 273 (1), an Act of Parliament must make provision, consistent with chapter 14 , for the establishment and functioning of provincial and metropolitan councils, and in particular, for -

a) the procedures of provincial and metropolitan and metropolitan councils;

b) the functions of chairpersons of provincial and metropolitan councils

c) the conditions of service of members of provincial and metropolitan councils; and

d) the appointment, conditions of service and removal of employees of provincial and metropolitan councils

\section{Provincial Councils}

The provincial councils are also called the non-metropolitan councils because their areas of jurisdiction cover more rural communities than urban areas.

It is important to understand that the Midlands Province will pose debate as it contains nearly an equal share: urban and rural areas. These are provincial (non - metropolitan) councils. There are eight (8) of them as follows:

- Manicaland

- Mashonaland Central

- Mashonaland East

- Mashonaland West

- Masvingo
- Matebeleland North

- Matebeleland South; and

- Midlands

Membership to provincial [non - metropolitan] council is clearly defined and provided for good governance

In terms of section 268 on provincial councils,

1) There is a provincial council for each province, except the metropolitan provinces, consisting of:

Membership of provincial councils

a) A chairperson of the council, elected in terms of section 272 ;

b) The senators elected from the province concerned

c) The two senator chiefs elected from the province concerned in terms of section 120 (1) (b);

d) The president and deputy president of the National Council of Chiefs, where their areas fall within the province concerned.

e) All the members of the National Assembly whose constituencies fall within the province concerned;

f) The women members of the National Assembly who are elected in terms of section 124 (1) (b) from the province covered;

g) The mayors and chairpersons by whatever title they are called, of all urban and rural local authorities in the province concerned

h) Ten persons elected by as systems of proportional representation referred to in subsection (3).

2) A person is qualified to be elected to a provincial council in terms of subsection (1) (h) if he or she is qualified for election as a Member of the National Assembly.

\section{Elections of provincial councils}

3) Elections to provincial councils must be conducted in accordance with the Electoral Law, which must ensure that the councillors referred to in subsection (1) (h) are elected under a party - list systems of proportional representation -

a) Which is based on the votes for candidates representing political parties in the province concerned in the general election for Members of the National Assembly; and

b) In which male and female candidates are listed alternatively, ever list being headed by a female candidate.

\section{Vacant seats of provincial councils}

4) The seats of a member of a provincial referred to in -

a) Paragraph (b), (c), (e) or (f) of subsection (1) becomes vacant if the member vacates his or her seat in Parliament;

b) Paragraph (g) of subsection (1) becomes vacant if the member ceases to be a mayor or chairperson of a local authority in the province concerned;

c) Paragraph (b) of subsection (1) becomes vacant in the circumstances set out in section 129, as if the member were a Member of Parliament.

\section{PROVINCIAL COUNCILS}

- Elected chairperson

- Senators

- Two senator chiefs 


\section{International Journal of Science and Research (IJSR) \\ ISSN (Online): 2319-7064 \\ Index Copernicus Value (2013): 6.14 | Impact Factor (2014): 5.611}

- President and deputy president - National Chief Council [where their areas fall within province concerned]

- Members of National Assembly (where their areas fall within province concerned)

- Women members of National Assembly

- Mayors and chairpersons of local authorities

- 10 persons elected by proportional representation

Powers and functions of Metropolitan and Provincial Councils

Provincial councils are legal institutions with structures which must perform certain definite functions:

\section{Powers and functions}

In terms of section 270 on the powers and functions of metropolitan and provincial councils,

1) A metropolitan or provincial council is responsible for the social and economic development of its province, including -

a) Planning and implementing social and economic development activities in the province;

b) Coordinating and implementing governmental programmes in its province;

c) Planning and implementing measures for the conservation, improvement and management of natural resources in its province;

d) Promoting tourisms in its province, and developing facilities for that purpose;

e) Monitoring and evaluating the use of resources in its province; and

f) Exercising any other functions, including political and legislative functions, that may be conferred or imposed on it by or under an Act of Parliament.

2) An Act of Parliament must provide for the establishment, structure and staff of metropolitan and provincial councils, and the manner in which they exercise their functions.

3) Members of a metropolitan or provincial council are accountable, collectively and individually, to residents of their province and the national government for the exercise of their powers and functions.

\section{Committees of Provincial Councils}

Due to high level of political participation at provincial and metropolitan government levels, their committee systems need to function in a certain regulated way

In terms of section 271, for the better exercise of their functions, metropolitan and provincial councils may establish committees but each such committee must be presided over by a member referred to in section 268 (1) (h).

\section{Chairpersons of Provincial Councils}

In terms of section 272 chairpersons of provincial councils.

1)At this first sitting after every general election, a provincial council must elect a chairperson from a list of act least two qualified persons submitted by -

a) the political party which gained the highest number of National Assembly seats in the province concerned; or

b) if there is no political party such as is referred to in paragraph (a), the political party which received the highest number of votes cast in the province in that general election for members of the National Assembly

2)A person is qualified for election as the chairperson of a provincial council if he or she is qualified for election as a Member of senate.

3) The office of chairperson of a provincial council is a public office but does not form part of the Civil Service.

4)Before commencing his or her duties, the chairperson of a provincial council must take before the clerk of the provincial council the oaths of loyalty and office in forms set out in the Third Schedule.

5) The chairperson of a provincial council may resign by announcing his or her resignation in person to the provincial council.

6) The chairperson of a provincial council must vacate his or her office -

a) On the day on which the provincial council first meets after a general election;

b) If he or she becomes disqualified to be a member of the provincial council

c) If a resolution for his or her removal from office is passed by at least two - thirds of the total membership of the provincial council; or

d) If he or she is removed from office by a tribunal referred to in subsection (7).

7) An Act on Parliament must provide for the establishment of an independent tribunal to exercise the function of removing chairpersons of provincial councils from office, but any such removal must only be on the grounds of -

a) Inability to perform the functions of their office due to mental or physical incapacity;

b) Gross incompetence

c) Gross misconduct

d) Conviction of an offence involving dishonest, corruption, or abuse of office; or

e) Wilful violation of the law, including a local authority by - law.

8)A chairperson of a provincial council does not vacate his or her office except in accordance with this subsection.

\section{General principles relating to Provincial Councils}

1) An Act of Parliament must make provision, consistent with this chapter, for the establishment and functions of metropolitan and provincial councils and, in particular. For -

a) The procedure of metropolitan and provincial councils;

b) The functions of a chairpersons of metropolitan sand provincial councils; and

c) The appointment, conditions of service and removal of employees of metropolitan and provincial councils.

2) The electoral Law must make provision, consistent with this Chapter, for the filling of vacancies in the seats of the members of provincial councils referred to in section 268 (1) (f) and in the offices of chairpersons of a provincial councils, which vacancies must be filled -

a) By persons belonging to the same political parties as those who previously held the seats or offices; and

b) Except in the case of chairpersons, by a person of the same gender sad the persons who previously held the seats. 


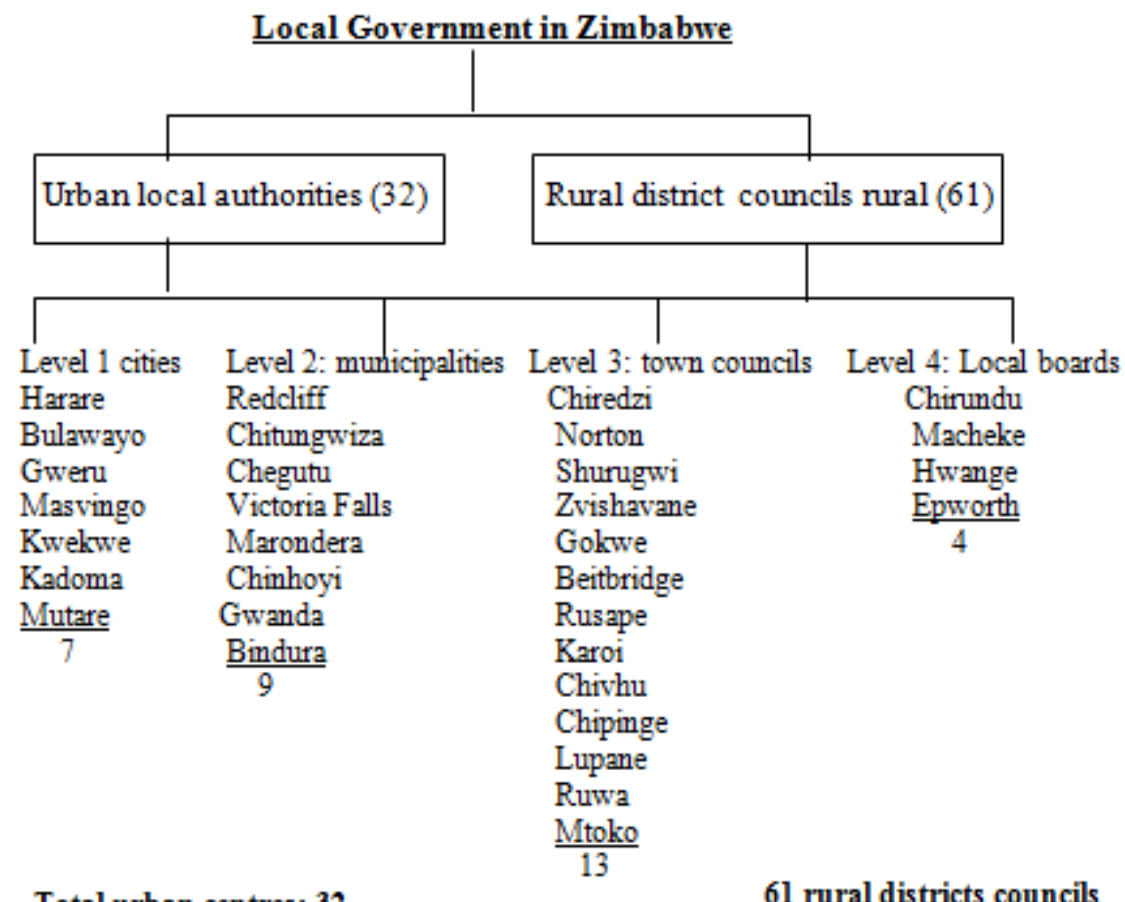

Total urban centres: $\mathbf{3 2}$

61 rural districts councils

c) The election of chairpersons, by whatever title they may be called, to preside over the councils referred to paragraph (b), and

d) The qualifications of members of the councils referred in paragraph (b).

3) Different classes of local authorities may be established for different rural areas, and two or more different areas may be placed under the management of a single local authority.

\section{Functions of local authorities}

In view of their position in the hierarchy of authorities in a state, the functions of local authorities must be defined by local authority.

4) The procedure for the election of persons referred to in subsection (2) must be set out in the Electoral Law.

5) An Act of Parliament may confer executive powers on the mayor or chairpersons of an urban local authority but any mayor or chairperson on whom such powers are conferred must be elected directly by registered voters in the areas of which the local authority has been established.

\section{Local authorities for rural areas}

In terms of section 275

1) There are rural local authorities established in accordance with this section, to represent and manage the affair of people in rural areas.

2) An Act of Parliament must provide for

a) The establishment of rural authorities;

b) The election, by registered voters in the rural areas concerned, of councillors to manager the affairs of the local authorities referred to in paragraph (a) and

\section{Parliament.}

In terms of section 276 ,

1) Subject to the Constitution and any Act of Parliament, a local authority has the right to govern, on its own initiative the local affairs of the people within the area for which it has been established, and has all the powers necessary for it to do so.

2) An Act of Parliament may confer functions on local authorities, including -

a) Power to make by - laws, regulations or rules for the effective administration of the areas for which they have been established;

b) Power to levy rates and taxes and generally to raise sufficient revenue for them to carry out their object and responsibilities.

\section{Elections to local authorities}

In terms of section 277 


\section{International Journal of Science and Research (IJSR) \\ ISSN (Online): 2319-7064 \\ Index Copernicus Value (2013): 6.14 | Impact Factor (2014): 5.611}

1) Elections of councillors of local authorities must be held

a) In the case of a general election of mayors and councillors or, concurrently with a general elections of Members of Parliament and President;

b) In the case of an election, other than a general election, to fill one or more casual vacancies, as soon as practicable after the vacancies have occurred.

2) Elections of mayors and chairpersons of local authorities, other than mayors or chairperson on whom executive powers have been conferred under section 274 (5), must be held at the first sitting of the councils concerned following a general election.

3) Except ass otherwise provides in sub - section (2) or an Act of Parliament, mayors, chairpersons and councillors of local authorities assume office on the day the President assumes office upon being sworn in after a general election.

\section{Tenure of seats of members of local authorities}

In terms of section 278

1) The seat of a mayor, chairperson or councillor of a local authority becomes vacant in the circumstances set out in section 129, as if he or she were a Member of Parliament, any reference to the Speaker or President of the Senate in Section $129(\mathrm{k})$ being constructed as a reference to the Member responsible for local government.

2) An Act of Parliament must provide for the establishment of an independence tribunal to exercise the function of removing from office mayors, chairpersons and councillor, but any removal must only be on the grounds of -
a) Inability to perform the function of their office due to mental or physical incapacity.
b) Gross incompetence;
c) Gross misconduct;
d) Conviction of an offence involving dishonestly, corruption or abuse of office; or
e) Wilful violation of the law, including a local authority by - law.
f) A mayor, chairperson or councillor of a local authority does not vacate his or her seat except in accordance with this section.

\section{Procedure of local authorities}

Systems and procedures:

- A system is defined as being made up of interacting and interrelated units, sub-units and sub-sub-units, constituting a whole or structure of which they are parts, with certain functions and responsibilities.

- Procedures are formal ways which establish customary ways of handling specific recurring activities usually involving group effort.

Source: S. B.M.Marume and A. S. Chikasha: 2015

In terms of section 279, an Act Parliament must provide for the procedure to be followed by councils of local authorities.

\section{General observations and recommendations}

1) For the first time in the political and constitutional history of Zimbabwe, a much more vibrant, representative, constitutional, democratic, provincial and metropolitan and local government is provided for, which permits for far more wider active participation by all communities in the policy decision - making process at provincial and local government levels.

2) However, a number of observations need to be made in an attempt to strengthen and operationalize the envisaged provincial and metropolitan and local government systems in this country.

\subsection{In order to preserve the values expounded in the preamble as:}

a) the preservation of national unity and the prevention of all forms of disunity and sessionism;

b) the democratic participation in government by all citizens and communities of Zimbabwe; and

c) the equitable allocation of national resources and the participation of local communities in the determination of development priorities within their areas; there must be devolution of powers and responsibilities to lower tiers of government in Zimbabwe.

\section{Recommendations}

1) It is highly recommended that a provincial administrator of the statuss equivalent to a deputy permanent secretary be appointed by the State President to be the chief executive official of the provincial authority whose main responsibilities will be:

- to represent the State President and central government in the province concerned;

- to keep an eye on the activities of the provincial government and administration; to promulgate provincial ordinances in the provincial gazette;

- to coordinate with the central government departments in the province;

- to ensure equitable allocation of financial resources by the central government to provincial and local authorities in the province concerned; and

- to ensure the provision of a uniform provincial government and administration throughout the country;

2) The establishment of an executive committee system of the provincial council under the chairmanship of the provincial administrator to be called the provincial administrator - in executive committee, with the provincial chairperson as its deputy chairperson, the executive committee will be responsible for implementing the provincial council policies, the composition should consist of the provincial administrator, the provincial council chairperson, and four councillors; and the executive committee will have power to employ staff;

3) The provincial councils should have power to make provincial ordinances which have legal effect; and

4) The provincial authorities should have powers over local authorities in the province concerned; and

5) The provincial authorities should coordinate the activities of local authorities in the province concerned in order to 


\section{International Journal of Science and Research (IJSR) \\ ISSN (Online): 2319-7064 \\ Index Copernicus Value (2013): 6.14 | Impact Factor (2014): 5.611}

ensure a coordinated, functional and effective provision and metropolitan government and administration system.

\section{Further Recommendations}

1) The cabinet ministers, deputy ministers, the speaker of Parliament, and Chairperson of he Parliamentary Select Committee on Public Accounts and the Parliamentary Select Committee of budget and Means should not be members of the provincial and metropolitan councils to minimise problems and challenges associated with possible conflict of interests.

2) To enable full and adequate attendance and debates in the provincial and metropolitan councils and Parliamentary sessions should not coincide but rather be far separated and be fixed in advance.

3) The provincial administrators and the provincial council chairpersons should appear before the Parliamentary Select Committee on Provincial Government and Administration to ensure proper use of public funds for their provinces; be made accountable.

4) The comptroller and Auditor - General should carry out audits of provincial and metropolitan authorities.

5) The provincial authorities should have power to impose certain rates and taxes, including land taxes calculated according to hectarage which a person may own or hold in the province concerned.
6) The provincial administrators, provincial council chairpersons and executive mayors should be the public office - bearers who work on a full time basis to ensure continuous, effective and adequate management of affairs owing to special and heavy responsibilities of their executive positions; otherwise all the other members should work on non - full time basis but shall receive allowances from the budget of the provincial council concerned.

7) The provincial and metropolitan councils should appoint and employ a provincial executive secretary who shall head and supervise the provincial departmental heads and the departments in implementing the policy decisions of the provincial and metropolitan councils. The provincial administrator shall handle political and high level duties while the provincial executive secretary should be responsible for provincial administration and implementation matters of the provincial or metropolitan government

8) The various Acts be amended to align themselves to the new Constitution, more specifically, the Urban Councils Act, Rural Districts Councils Act, Provincial Authorities Act, the Public Service Act, Social Welfare Act, the General Administration Act, and many others.

9) All metropolitan and provincial councils should prepare and table their annual reports before Parliament to ensure equitable, sustainable and consistent development of all Zimbabwean provinces districts and communities.

Illustration No. 7

The Zimbabwean hierarchy of authorities (simplified)

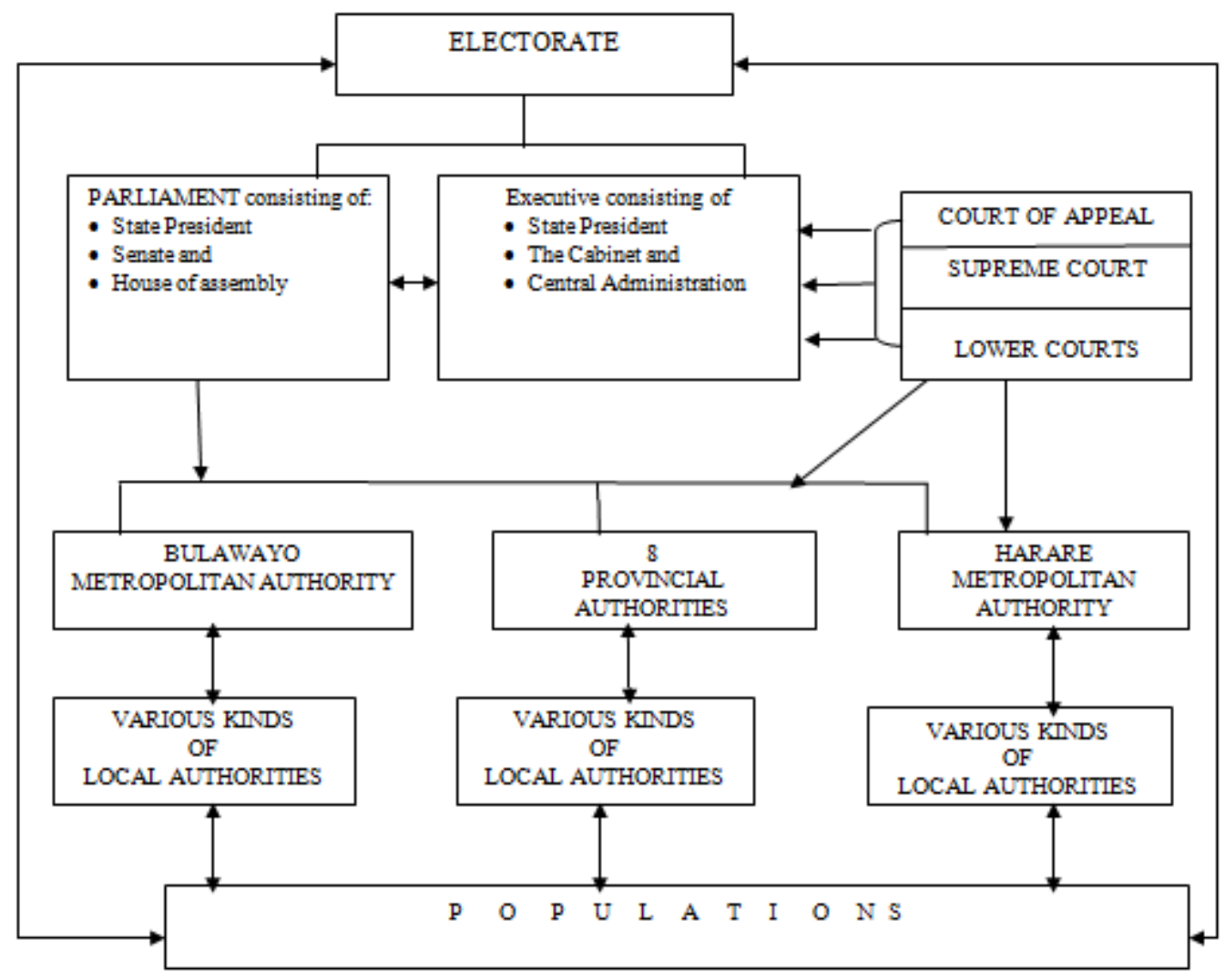


International Journal of Science and Research (IJSR)

ISSN (Online): 2319-7064

Index Copernicus Value (2013): 6.14 | Impact Factor (2014): 5.611

Illustration No. 8

Provincial government machinery for control of local authorities

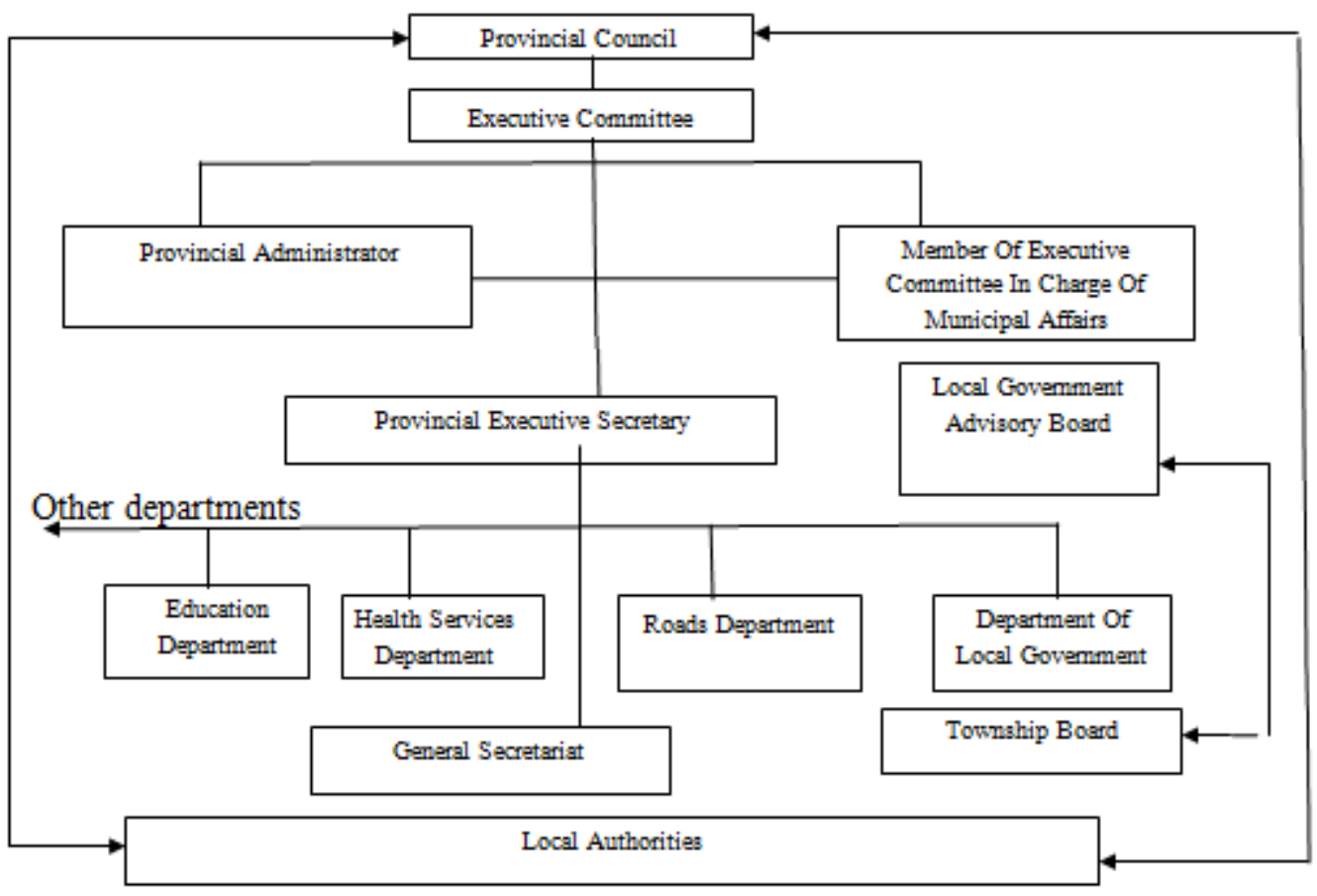

Illustration No. 9

The Zimbabwean hierarchy of authorities

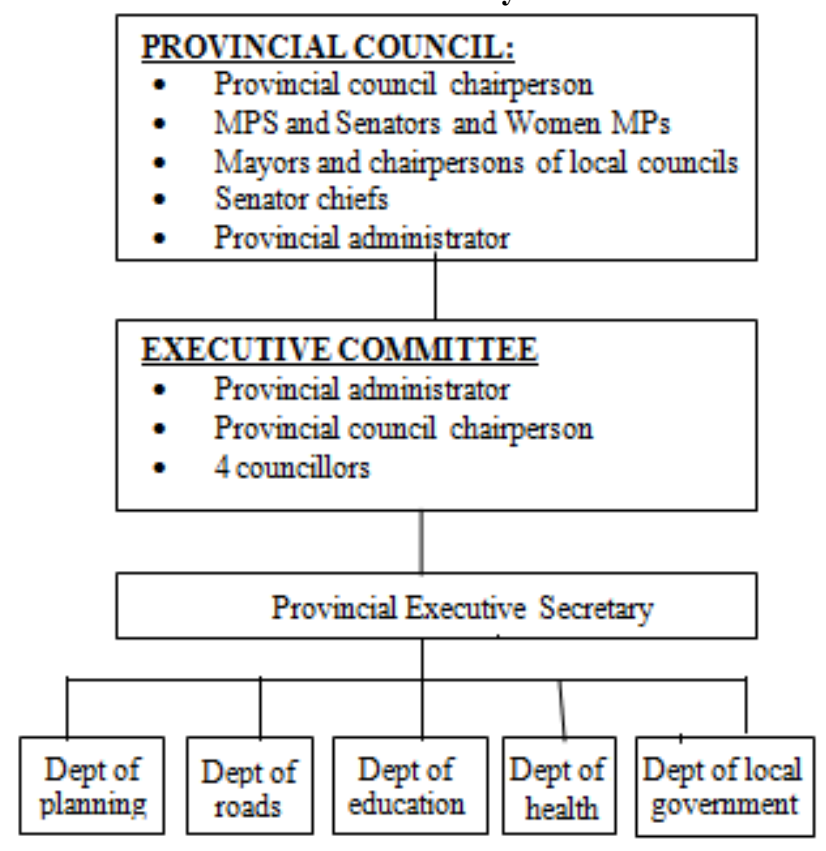

\section{References}

[1] J. J. N Cloete: Central, Provincial and municipal institutions of South Africa: J. L. van Schaik, Pretoria: 1982.

[2] J. J. N. Cloete: Provincial and municipal government and administration: J. L. van Schaik, Pretoria, 1977.

[3] J. J. N. Cloete: Introduction to Public Administration: J. L. van Schaik: Pretoria, 1985.

[4] S. B. M. Marume and A. S. Chikasha: Provincial government and administration in Zimbabwe: LAP Lambert Academic Publishing: Berlin, Germany, 2015 [ISBN 978-3-659-24142-0]
[5] S. B. M. Marume: Public Administration: special contemporary problems and challenges; LAP Lambert Academic Publishing, Berlin, Germany, 2015 [ISBN 978-3-659-75883-6]

[6] S. B. M. Marume: Pre-colonial political history of Shona Great Zimbabwe States: LAP Lambert Academic Publishing: Berlin, Germany 2015 [ISBN 978-3-65977410-2]

[7] S. B. M. Marume: Normative factors in public administration: LAP Lambert Academic Publishing: Berlin, Germany 2015 [ISBN 978-3-659-49921-0]

[8] S. B. M. Marume: International Politics: Africa on subregional systems basis: LAP Lambert Academic Publishing: Berlin, Germany 2015 [ISBN 978-3-65980183-9] 


\section{International Journal of Science and Research (IJSR) \\ ISSN (Online): 2319-7064}

Index Copernicus Value (2013): 6.14 | Impact Factor (2014): 5.611

[9] Zimbabwe Government: Constitution of Zimbabwe Amendment [No. 20, 2013] Act, 2013: Government Printer, Harare, 2013.

\section{Author Profile}

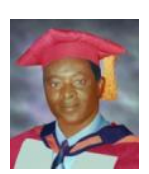

Dr. S. B. M. Marume, BA, Hons BA, MA, MAdmin, MSoc Sc, $\mathrm{PhD}$ is Senior Lecturer and Acting Chairperson - Department of Public Administration. Samson Brown Muchineripi: born on 15 July 1943; a former senior civil servant for 37 years and deputy permanent secretary; ten years as a large commercial former; well travelled domestically, regionally [SADC countries and Africa's Kenya, Ethiopia, Sudan, Libya, Uganda]; and internationally [Washington, New York and California in USA; Dublin and Cork in Ireland; Netherlands, France, former Yugoslavia Belgrade; Rome and Turin in Italy; Cyprus - Nicosia; Athens - Greece; Bejing - China; Singapore; Hong Kong; Japan; and $\mathrm{UK}]$; six years as management consultant and part - time lecturer and $\mathrm{PhD} / \mathrm{DPhil}$ thesis supervisor, internal and external examiner; researcher and writer and currently senior lecturer and acting chairperson of Department of Public Administration in Faculty of Commerce and Law of Zimbabwe Open University; is a graduate BA, special Hons BA, MA [Public Administration] [Unisa, South Africa], MAdmin magna cum laude in transport economics, MSoc sc cum laude in international politics, $\mathrm{PhD}$ summa cum laude in public administration [CUAS, California, United States of America]. 